\title{
Entre cinismos, posturas críticas, subjetividades precárias e sofrimento psíquico: aportes de um livro kínico
}

\author{
Between cynicisms, critical postures, precarious subjectivities and \\ psychic suffering: contributions from a kinist book
}

\author{
Entre cinismos, posturas críticas, subjetividades precarias y \\ sufrimiento psíquico: aportes de un libro kínico
}

\begin{abstract}
À PROCURA DE UM MUNDO MELHOR: APONTAMENTOS SOBRE O CINISMO EM SAÚDE. Castiel LD, Xavier C, Moraes DR. Rio de Janeiro: Editora Fiocruz; 2016. 400p. ISBN 978-85-7541-482-8.
\end{abstract}

doi: 10.1590/0102-311X00211618

O livro À Procura de um Mundo Melhor: Apontamentos sobre o Cinismo em Saúde deve ser lido como uma análise kínica - crítica, verdadeira, ousada e irônica - do neoliberalismo contemporâneo e suas consequências para a vida prática, concentrando tal análise no campo da saúde coletiva.

Há dois temas presentes no livro que serão privilegiados nesta resenha - o cinismo e o sofrimento psíquico. A categoria cinismo atravessa todo o livro e sofrimento psíquico é um tema menos evidente, mas de extrema importância, na medida em que é um dos efeitos nefastos do cinismo contemporâneo. É indiretamente referido no título, na ideia de "procura de um mundo melhor”. Poderíamos dizer "pró-cura”, isto é, há uma busca por saber sobre o mundo, mas há também uma busca de cura do mundo. Dada a perspectiva do livro, a cura do mundo é condição necessária para a cura dos sujeitos.

O cinismo é categoria central para compreender as dinâmicas de racionalização que regem as diversas relações no capitalismo contemporâneo. Há um modo cínico naturalizado e insolente de funcionamento das estruturas que operam no neoliberalismo, portanto, não deve ser compreendido simplesmente como uma distorção de princípios morais, mas como regime de economia do discurso. Para Safatle 1, o cinismo é efeito de estruturas normativas duais que fazem convergir duas racionalidades normativas contraditórias. Há uma configuração paradoxal em que se produz continuamente a fragilização das normas enunciadas pelo próprio capitalismo; uma espécie de autofagia permanente.

Vemos uma forma de administração da insatisfação do desejo, donde esta é investida pelo capitalismo como sintoma tratável por meio de objetos-mercadorias com vistas a uma suposta completude. Trata-se de um modo de produção constante de insegurança e angústia em que o sujeito não é apenas consumidor, incitado a consumir artefatos que supostamente aliviariam seu mal-estar, mas é também consumido. Resta saber como lidamos com esse sofrimento; de maneira cínica, prescrevendo e fazendo uso de psicotrópicos ou de maneira kínica, implicando-se na produção do sofrimento próprio e do outro e na luta contra o declínio das relações pautadas no modo de funcionamento monetário gerencialista.

A clarificação conceitual do cinismo é realizada com rigor teórico e o formalismo adotado é um meio e não um fim em si; é um meio - fértil - para sustentar a crítica que segue por todo o livro. São apresentados diferentes termos para sublinhar usos díspares do "cinismo": kinismo, cinismo, çinismo e cenismo. 
Kinismo carrega o sentido da escola filosófica dos antigos sábios gregos e faz referência ao filósofo-cão, aquele que cultiva o despudor, late e morde para afastar os homens dos perigos e que, frente aos poderes constituídos, diz o que é preciso dizer, destituindo velhos valores. Os kínicos vivem e agem contra as ideias dos opositores e têm a liberdade de se moverem para onde desejam, sobretudo porque vivem uma existência anti-idealista. Kinismo é uma filosofia da existência que se funda sobre três bases: (1) atyphia ou desanuviamento dos olhos e das mentes, ver como as coisas são; (2) autárkeia ou autossuficiência, estar preparado para qualquer adversidade; e (3) parrhesía ou dizer a verdade, chamar as coisas pelos nomes certos.

Cinismo é o uso moderno do termo, um desvio cínico que traz o sentido oposto ao dos gregos. Trata-se de uma falsa consciência ilustrada, pautada em uma falsa superioridade que busca autopreservar sua ilusão. O cínico mente primeiro para si e depois para os outros. A ação política do Estado é um fenômeno cínico exemplar que domina para se autoconservar e mente para dominar, e os indivíduos de posse do poder tornam-se opressores. Apesar do cínico não ser vencido pela argumentação, o kinismo, com seu gesto pedagógico e desnudador e sua postura irônica, pode vencê-lo.

Çinismo é o cinismo precário, dos oprimidos, da massa levada pelos cínicos ilustrados. É o cínico do cotidiano, medíocre, vulgar, que se acha o espécime mais elevado e que ignora tudo aquilo que não pode se tornar fonte de lucro imediato para si. Não é poderoso como o grande cínico, mas é tão escravo como ele - das instituições cínicas, do mundo que lhe acena desejos impossíveis e de seus próprios fetiches. Por fim, cenismo é um cinismo digno, performativo, referido à cena teatral. Uma estratégia de sobrevivência dos que dissentem dos rumos utilitaristas do mundo.

Após a exploração rigorosa do termo, o "cinismo nosso de cada dia” é evidenciado na saúde coletiva. Foucault 2, nos anos 1970, nos alertou que não haveria campo da vida humana e social que não tivesse sido convertido em objeto de ação médica. Porém, a própria medicina não está fora da racionalidade neoliberal cínica de hoje, e então não há campo da vida humana e social que não esteja submetido aos meandros do gerencialismo dominante.

Tal racionalidade está presente em todos os âmbitos da vida, mesmo naqueles que não têm relação com o domínio monetário, contaminando as relações sociais em seus mínimos detalhes. A eficácia instrumental faz confundir o verdadeiro com o eficaz em uma lógica utilitarista marcada pelo cinismo ético, negando a dignidade ao neutralizar, manipular e subjugar o outro, tornando as vidas, vidas nuas 3 .

Na saúde, a financeirização da vida impera e ocorre na fetichização das medidas e dos números. Nessa seara está a hiperprevenção médico-epidemiológica em que se calcula os riscos em um ambiente de práticas cínicas produtoras de insegurança e medo, gerando ansiedade e submissão a normas de comportamento e... tratamento com psicotrópicos. Há uma estrutura normativa dual e ambígua em que o próprio campo da saúde é propulsor e supostamente curador de ansiedade. Medicamentalidade é o termo usado para fazer referência ao tipo de governamentalidade própria da saúde hoje.

Os médicos que prescrevem ou que cospem preceitos morais de comportamento não para pacientes, mas para supostos "empresários de si”, são çinicos. Assim como os gestores dos serviços de saúde que cobram dos profissionais produtividade no lugar do cuidado e, ao mesmo tempo, promovem um discurso cínico próprio da sociedade securitária em que vivemos, de que pacientes e médicos devem ser protegidos.

Çinicos são também os coordenadores de pósgraduação que respondem às exigências produtivistas da Coordenação de Aperfeiçoamento de Pessoal de Nível Superior (Capes) sem crítica. As instituições cínicas às quais pertencem transformam indivíduos em meios para seus fins, donde os gestores são apenas rebanho em busca de sobrevivência ou prestígio. No bojo do cinismo publicacionista e da competitividade, os autores apontam duas dimensões principais. $\mathrm{O}$ rechaço 
cínico à tradição crítica por meio da desvalorização do ensaio por carecer de "evidência científica" e o dopping acadêmico - ora condenado, ora estimulado - para se adequar às exigências de competitividade no meio.

Não é difícil imaginar a extensão do sofrimento psíquico em uma sociedade que se organiza em torno do diagrama da avaliação e que cultua a performance individual como imperativo moral 4. A cínica promessa de felicidade individual e sucesso garantido faliu evidenciando que individualização competitiva e isolamento psíquico provocam "mais danos do que benefícios".

As tentativas de alívio do sofrimento, no entanto, não têm considerado essa dimensão estrutural e têm sido dirigidas para os dispositivos biotecnocientíficos no intuito de ultrapassar os limites do corpo e da vida. Tentativa fracassada que, no limite, faz da morte uma incerteza valendo-se da aposta de que por meio da gestão dos riscos é possível alcançar a imortalidade.

A finitude posta em questão é uma forma radical de recusa do desamparo constitutivo, recusa esta própria do funcionamento neoliberal que aposta na onipotência narcísica em detrimento da formação de laços sociais para lidar com o desamparo. Ao negar a morte, produz-se morte. A vida, que deve ser reproduzida permanentemente, só é possível na interação.

Se a racionalidade cínica traz consigo a falência da crítica, segundo Safatle 1, pois é uma falsa consciência esclarecida em que os sujeitos sabem que agem da forma que agem, mas atuam como se não soubessem, os autores do livro fazem diferente. Sabem como agem e se responsabilizam pelo que dizem. Um livro kínico, um alento que vale menos pelos pontos no Lattes e mais pelo incômodo provocado. Afinal, cão que Lattes, não morde. Uma busca pela cura do mundo; por um mundo e por sujeitos kínicos!

\section{Paula Gaudenzi}

${ }^{1}$ Instituto Nacional de Saúde da Mulher, da Criança e do Adolescente Fernandes Figueira, Fundação Oswaldo Cruz, Rio de Janeiro, Brasil.

paula.gaudenzi@gmail.com

1. Safatle V. Cinismo e falência da crítica. São Paulo: Boitempo Editorial; 2008.

2. Foucault M. Crise da medicina ou crise da antimedicina. Verve: Revista do NU-SOL 2010; 18:167-94.

3. Agamben G. Profanações. São Paulo: Boitempo Editorial; 2005.

4. Ehrenberg A. O culto da performance: da aventura empreendedora à depressão nervosa. Aparecida: Ideias \& Letras; 2010. 